\title{
EU Case Law Developments on Age Discrimination
}

\author{
Catarina Vieira Peres*
}

\begin{abstract}
The principle of non-discrimination on grounds of age has been declared an autonomous EU law principle by the European Court of Justice. This principle has been specified in a Directive, but its scope of application is currently limited to employment and occupational activities. The Directive protects both younger and older workers from being directly or indirectly discriminated due to their age. However, given the specificity of age as a factor of discrimination, the Directive allows the Member States to apply some derogations to this principle if, within the context of national law, they are objectively and reasonably justified by a legitimate aim.

In the present contribution, we intend to analyse the Court's application and interpretation of the principle of non-discrimination on grounds of age as established in the Directive and comment on some of the most relevant preliminary rulings. In many of these rulings, the Court was asked whether the Directive precludes national norms which establish a mandatory retirement age or foresee the termination of the employment contract when the worker reaches a certain age.

The Court's interpretation of the principle of non-discrimination on grounds of age, as established in the Directive, could contribute to easing some of the EU's current economic, social and demographic challenges and to the improvement of European workers' lives; however, the Court seems to accept Member States' derogations to this principle too easily.
\end{abstract}

KEYWORDS: Age discrimination - youth unemployment - labour market - employment policy - intergenerational balance

\footnotetext{
* Catarina Vieira Peres is a PhD Student at the School of Law of Universidade Católica do Porto, 4169-005 Porto, Portugal. c.vieira.peres@gmail.com.
} 
According to the Court of Justice (CJ), the principle of non-discrimination on grounds of age is a general principle of European Union (EU) law. ${ }^{1}$ The operation of this principle has been laid down in Directive 2000/78/CE (the Directive), ${ }^{2}$ albeit only as regards employment and occupation. This Directive has been the subject of numerous preliminary rulings questioning the validity of national rules which allegedly introduce a discriminatory treatment on grounds of age. In contrast with the United States of America, where the Federal Age Discrimination in Employment Act only offers protection to older workers, based on the premise that these people are especially vulnerable, the EU Directive precludes national dispositions which are discriminatory to people of a certain age group: either by disfavouring younger employees ${ }^{3}$ or by establishing regimes which are detrimental to older workers.

Abercrombie \& Fitch Italia ${ }^{4}$ is an example of a case integrating the first group, i.e. where the national provision is detrimental to younger employees. In this preliminary ruling the CJ was asked whether the Directive would impede an Italian provision which authorised employers to conclude on-call contracts with workers under 25 years of age, whatever the nature of the services to be provided, and to dismiss them as soon as they reached that age. The $\mathrm{CJ}$ held that the Directive did not preclude such provision since it aimed to increase the flexibility of the labour market and employment levels of younger generations.

Other examples of cases in this first group are Lesar ${ }^{5}$ and Felber, ${ }^{6}$ where the CJ declared that the Directive did not preclude national legislation which excluded the taking into account of periods of apprenticeship, employment (Lesar case) and school education (Felber case) completed by a civil servant before reaching the age of 18 for the purpose of granting a pension entitlement and the calculation of its amount, since it constituted

\footnotetext{
${ }^{1}$ Judgment of 22 November 2005, Mangold v. Rüdiger Helm, C-144/04, EU:C:2005:709, paragraph 75. ${ }^{2}$ Council Directive (EC) No. 2000/78/CE of 27 November 2000 (Official Journal L 303, 3 December 2000, 16-22).

${ }^{3}$ See Marshall Kapp, "Looking at age discrimination laws through a global lens", Generations Journal of the American Society on Aging 37, no. 1 (2013): 70-75.

${ }^{4}$ Judgment of 19 July 2017, Abercrombie \& Fitch Italia v. Antonino Bordonaro, C-143/16, EU:C:2017:566.

${ }^{5}$ Judgment of 16 June 2016, Franz Lesar v. Beim Vorstand der Telekom Austria, C-159/15, EU:C:2016:451.

${ }^{6}$ Judgment of 21 January 2015, Georg Felber v. Bundesministerin für Unterricht, Kunst und Kultur, C-529/13, EU:C:2015:20.
} 
an expression of the freedom enjoyed by Member States (MS) to fix an age of admission to occupational social security schemes.?

Under discussion in the Kristensen case was an occupational pension scheme which allegedly discriminated younger people, as the employers paid, as part of their income, pension contributions which increased with age. The CJ was also of the opinion that the Directive was not opposed to such scheme. According to the Court, even though the scheme established a difference in treatment on grounds of age, it was not discriminatory, since it enabled older workers, who joined the company at a later stage in their working life, to build up reasonable retirement savings over a relatively short contribution period and was justified by the need to cover the risks of death, incapacity and serious illness, the cost of which increases with age. ${ }^{8}$

However, in Unland ${ }^{9}$ and Specht ${ }^{10}$ the CJ qualified as discriminatory and precluded by the Directive provisions of national law under which the basic pay of civil servants was determined, at the time of their appointment, solely according to their age.

Regarding the second group of cases, where the discrimination works against older employees, there is a high number of preliminary rulings raising the question of whether national norms establishing the automatic termination of employment relationships when workers reach a certain age are compatible with the Directive. ${ }^{11}$

\footnotetext{
${ }^{7}$ It is interesting to compare these two cases with the Judgment of 18 June 2009, David Hütter $v$. Technische Universität Graz, C-88/08, EU:C:2009:381. In this case, even though the norms at issue were quite similar with the cases above, the ECJ found that the Directive precluded the national provision, since it was deemed as inappropriate to pursue its aim, which consisted in not treating general education less favourably than vocational education.

${ }^{8}$ Judgment of 26 September 2013, Glennie Kristensen v. Experian, C-476/11, EU:C:2013:590.

9 Judgment of 9 September 2015, Daniel Unland v. Land Berlin, C-20/13, EU:C:2015:561.

${ }^{10}$ Judgment of 19 June 2014, Thomas Specht and others v. Land Berlin and Bundesrepublik Deutschland, C-501/12, EU:C:2014:2005.

${ }^{11}$ Cases dealing with the validity of compulsory retirement measures: Judgment of 16 October 2007, Félix Palacios de Villa v. Cortefiel Servicios SA, C-411/05, EU:C:2007:604; Age Concern England v. Secretary of State for Business Enterprise and Regulatory Reform, Judgment of 5 March 2009, C-388/07, EU:C:2009:128; Judgment of 12 January 2010, Domnica Petersen v. Berufungsausschuss für Zahnärzte für den Bezirk Westfalen-Lippe, C-341/08, EU:C:2010:4; Judgment of 12 October 2010, Gisela Rosenbladt v. Oellerking Gebäudereinigungsges, C-45/09, EU:C:2010:601; Judgment of 18 November 2010, Vasil Ivanov Georgiev v. Tehnicheski Universitet - Sofia, filial Plovdiv, C-250/09 and C-268/09, EU:C:2010:699; Judgment of 13 September 2011, Reinhard Prigge and others $v$. Deutsche Lufthansa AG, C-447/09, EU:C:2011:573; Judgment of 21 July 2011, Gerhard Fuchs and Peter Köhler v. Land Hessen, C-159/10 and C-160/10, EU:C:2011:508; Judgment of 5 July 2012,
} 
Also in the second group, there are various cases discussing the compatibility of national legislation which sets a maximum age for recruitment to certain posts with the Directive. This issue was discussed in the Wolf, ${ }^{12}$ Sorondo ${ }^{13}$ and Pére $z^{14}$ cases, where the Court gave divergent answers.

The CJ was also asked, in Lange, ${ }^{15}$ whether a taxation scheme which only allowed persons under the age of 30 to deduct in full vocational training costs from their taxable income was not discriminatory to older people. The Court answered that, as long as such scheme could be considered an appropriate and necessary measure to promote the access of young people to training and to improve their position on the labour market, it was not precluded by the Directive.

Three preliminary rulings originating in Denmark - Andersen, ${ }^{16}$ Landi $^{17}$ and Toftgaard ${ }^{18}$ - raised the question whether the Directive precluded national legislation which denied workers, solely for the reason that they were eligible for an old-age pension, the right to claim a severance allowance. Such norms aimed to prevent the allowance from being claimed by persons who were not seeking a new employment and would receive a replacement income in the form of a retirement pension. Once again, the CJ reached disparate conclusions. In Andersen and Toftgaard, the EU judicature found that such measures violated EU law since they deprived employees who wished to remain in the labour market from receiving a severance allowance merely because they could, due to their age, draw a retirement pension. In Landin, though, the CJ decided that the Directive did not preclude such measure as long as it was justified by a legitimate aim

Torsten Hörnfeldt v. Posten Meddelande AB, C-141/11, EU:C:2012:421; Judgment of 6 November 2012, European Commission v. Hungary, C-286/12, EU:C:2012:687.

${ }^{12}$ Judgment of 12 January 2010, Colin Wolfv. Stadt Frankfurt am Main, C-229/08, EU:C:2010:3.

${ }^{13}$ Judgment of 15 November 2016, Gorka Salaberria Sorondo v. Academia Vasca de Policía y Emergencias, C-258/15, EU:C:2016:873.

${ }^{14}$ Judgment of 13 November 2014, Mario Vital Pérez v. Ayuntamiento de Oviedo, C-416/13, EU:C:2014:2371.

${ }^{15}$ Judgment of 10 November 2016, J. J. de Lange v. Staatsscretaris van Financiën, C-548/15, EU:C:2016:850.

${ }^{16}$ Judgment of 12 October 2010, Ingeniørforeningen i Danmark v. Region Syddanmark (Andersen), C-499/08, EU:C:2010:600.

${ }^{17}$ Judgment of 26 February 2015, Ingeniørforeningen i Danmark v. Tekniq (Landin), C-515/13, EU:C:2015:115.

${ }^{18}$ Judgment of 26 September 2013, Dansk Jurist- og Økonomforbund v. Indenrigs- og Sundheds Ministeriet (Toftgaard), C-546/11, EU:C:2013:603. 
and could be considered an appropriate and necessary method to achieve such aim. ${ }^{19}$

\section{Legal background}

The Treaty of Amsterdam, in 1997, was the first to identify age as a factor of discrimination. Nonetheless, age-related issues have been part of the EU's political agenda, at least, since $1982 .{ }^{20}$ Today, art. 19 , no. 1 of the Treaty on the Functioning of the EU (TFEU) confers power to the Council to take appropriate action to combat discrimination based on various factors, among them age. Article 21, no. 1 of the EU Charter of Fundamental Rights, which has the same legal value as the Treaties since 2009, prohibits discrimination on grounds of age, and art. 25 recognises the rights of the elderly to lead a life of dignity and independence and to participate in social and cultural life. ${ }^{21}$

As mentioned above, Directive 2000/78/CE establishes a general framework for equal treatment, but only regarding employment and occupation. Unfortunately, since 2008, the Commission's proposal to combat discrimination outside the employment field finds itself blocked in the Council. ${ }^{22}$

\section{The controversial Mangold case and the principle of non-discrimi- nation on grounds of age as a general principle of EU law}

Interpretative doubts regarding the Directive began to surge even before the time limit for its implementation had expired. In the first preliminary ruling, Mangold, the CJ was asked about the compatibility with EU law of a German provision which authorised, without restrictions, the conclusion

\footnotetext{
${ }^{19}$ The CJ justified the disparity in solutions due to the fact that the provision discussed in Landin, unlike in the other cases, did not appear capable of causing a significant loss of income to the departing employee in the long term.

${ }^{20}$ Elaine Dewhurst, "Intergenerational balance, mandatory retirement and age discrimination in Europe: How can the ECJ better support national courts in finding a balance between the generations?", Common Market Law Review 50, no. 5 (2013): 1333-1362.

${ }^{21}$ For a detailed description of the evolution of EU's law concern with seniority see Anne MeyerHeine, "La prise en compte des seniors par un traité sexagénaire: Pour une nouvelle orientation des politiques publiques", Revue de l'Union Européene 619 (2018): 370-380.

${ }^{22}$ Some MS question the need for the Commission's proposal, which is seen as infringing national competence on certain matters and as conflicting with the principles of subsidiarity and proportionality. Issues are also raised regarding legal clarity and consistency with other legal acts, budgetary implications, costs and implementation.

See http://www.europarl.europa.eu/legislative-train/theme-area-of-justice-and-fundamentalrights/file-anti-discrimination-directive.
} 
of fixed-term contracts of employment once the worker had reached the age of 52, as long as there was no close connection with an earlier contract of employment of indefinite duration concluded with the same employer. It is worth noting that this provision had been amended, in order to lower the age limit from 58 to 52, during the period prescribed for transposing the Directive.

Mangold was a special case because not only was the Directive being invoked in a dispute between two private parties (an employer and an employee), but, as mentioned above, the time limit to implement the Directive had not yet expired.

The CJ, referring to the case Inter-Environnement Wallonie case, ${ }^{23}$ stated that, even though the transposition period had not yet expired, MS may not, during such period, adopt measures that may seriously compromise the attainment of the result prescribed by the Directive. ${ }^{24}$

In any case, according to the Court, it was not the Directive that introduced the principle of equal treatment in the field of employment and occupation, "the source of the actual principle underlying the prohibition of those forms of discrimination being found [...] in various international instruments and in the constitutional traditions common to the Member States", ${ }^{25}$ therefore "the principle of non-discrimination on grounds of age must thus be regarded as a general principle of Community law". ${ }^{26}$

From there the CJ drew the conclusion that it is the responsibility of national courts, hearing a dispute involving the principle of non-discrimination in respect of age, to ensure that those rules are fully effective and to set aside any provision of national law which may conflict with that law. ${ }^{27}$ The exact nature of the obligation imposed on national judicatures remained vague and unclear, as confirmed by the questions brought before the $\mathrm{CJ}$ in the aftermath of the Mangold case. ${ }^{28}$

Unlike what is sometimes affirmed, the CJ did not attribute horizontal effect to the Directive. Instead, the Court proclaimed the principle of nondiscrimination on grounds of age as a general EU law principle, which

\footnotetext{
${ }^{23}$ Judgment of 18 December 1997, Inter-Environment Wallonie v. Région Wallone, C-129/96, EU:C:1997:628.

${ }^{24}$ Paragraph 28 of Mangold.

${ }^{25}$ Paragraph 74 of Mangold.

${ }^{26}$ Paragraph 75 of Mangold.

${ }^{27}$ Paragraph 77 of Mangold.

${ }^{28}$ Elise Muir, "Of ages in - and edges of - EU law", Common Market Law Review 48 (2011): 50.
} 
allows national courts to apply it directly when analysing national provisions in potential conflict with the said principle. ${ }^{29}$

The $\mathrm{CJ}$ then declared that EU law precluded a national provision such as the one at issue in the proceedings.

The Mangold case was highly criticised, both by Advocate-Generals (AG) in posterior opinions ${ }^{30}$ and scholars ${ }^{31}$ who believe that the CJ took a precipitated decision, casting doubts over the principle of direct effect and leading to a situation of considerable legal uncertainty.

The Court was also condemned for failing to present an in-depth justification for its decision. Even though it is true that the international instruments mentioned in the case establish the principle of non-discrimination or equality, they do not specifically refer to age, ${ }^{32}$ and the same might be said in relation to the constitutional traditions of the various MS - the majority does not foresee age as a discrimination factor. ${ }^{33}$

\footnotetext{
${ }^{29}$ Jans H. Jans, "The effect in national legal systems of the prohibition of discrimination on grounds of age as a general principle of community law", Legal Issues of Economic Integration 34 (2007): 62. Olivier Leclerc, "Le contrat de travail des seniors à l'épreuve du droit communautaire", Recueil Dalloz (2006): 557-561.

${ }^{30}$ See opinion of AG Sharpston in Maria-Luise Lindorfer v. Council of the European Union, C-227/04, EU :C :2005 :656, paragraph 58; opinion of AG L. A. Geelhoed, in Judgment of 11 July 2006, Chacón Navas v. Eurest Colectividades, C-13/05, EU:C:2006:184, paragraphs 46-56; opinion of AG Ján Mazák, in Palacios, EU:C:2007:106, paragraphs 87-97; opinion of AG Damáso Colomer in Judgment of 24 April 2008, Michaeler v. Arbeitsinspektorat der Autonomen Provinz Bozen, C-55/07 and C-56/07, EU:C:2008:42, paragraphs 22-23; opinion of AG Sharpston, in Judgment of 23 September 2008, Birgit Bartsch v. Bosch und Siemens Hausgeräte Altersfürsorge, C-427/06, EU:C:2008:297, paragraphs 31-33.

${ }^{31}$ Joël Cavallini, "De la suppression des restrictions à la conclusion d'un contrat à durée déterminée lorsque le salarié est un senior", La Semaine Juridique Social 1414 (2005): 25-28; Olivier Dubos, "La cour de justice, le renvoi préjudiciel, l'invocabilité des directives: de l'apostasie à l'hérésie?", La Semaine Juridique Edition Générale 26 (2006): 1295-1297; Leclerc, "Le contrat de travail"; Anne-Sophie Petitdemange, "Une application anticipée des directives non transposées?", Gazette $d u$ Palais 102-103, no. 1 (2006): 22-23. M. Nicolella, Editorial Comments, "Horizontal direct effect - a law of diminishing coherence?”, Common Market Law Review 43 (2006): 1-8. Thomas Papadopulos, "Criticizing the horizontal direct effect of the EU general principle of equality", European Human Rights Law Review 4 (2011): 437-447.

${ }^{32}$ E.g. Conventions no. 100 and 111 of the International Labour Organization.

${ }^{33}$ Jans, "The Effect", 65. Also in this line, Norbert Reich, General Principles of EU Civil Law (Cambridge: Intersentia Publishing, 2014) 68. On Mangold's implications see Filippo Fontanelli, "General principles of the EU and a glimpse of solidarity in the aftermath of Mangold and Kücükdeveci”, European Public Law 17 (2011): 225-240. In contrast with Europe, the US has a long legal history of age discrimination, see Kapp, "Looking at age discrimination". According to this author, among the Constitutions of the MS only the Portuguese and the Finnish refer expressly to age as a factor of discrimination.
} 
Furthermore, some authors question the Court's need to establish the principle of non-discrimination on grounds of age as an autonomous principle, since the Court could have solved the case by limiting itself to finding a transgression to the general principle of equality. ${ }^{34}$ According to these authors, age is a minor form of discrimination which cannot be combated with the same rigor as the other forms of discrimination, such as race, gender or nationality.

Regardless of the proclamation of the principle of non-discrimination on grounds of age, in Bartsch, when asked whether the principle of nondiscrimination on grounds of age precluded a national norm which provided that the surviving spouse's pension would not be granted if they were 15 years younger than the deceased former employee, the CJ considered that the EU law principle was not applicable to this particular case since the national provision had no link with EU law: it was not an implementing measure of the Directive and the death of the employee had occurred before the time limit for transposing the Directive had expired.

Later, in the Kücükdeveci ${ }^{35}$ case, the CJ confirmed the existence of a principle of non-discrimination on grounds of age, which must be regarded as a general principle of EU law. According to the Court, this principle predates the Directive which was adopted in order to give it specific expression. ${ }^{36}$ In an effort to clarify previous case law, the CJ reaffirmed that, in order for the principle to apply, the case must fall within the scope of EU law. This link was found to be present in Kücükdeveci where, unlike the Bartsch case, the alleged discriminatory behaviour was adopted after the expiry of the period prescribed to transpose the Directive.

\section{The interpretation of the Directive according to the EU judicature}

According to art. 2 no. 1 of the Directive, the principle of equal treatment implies the absence of direct or indirect discrimination. Under the terms of no. 2, direct discrimination occurs when one person is treated

\footnotetext{
${ }^{34}$ Frédérique Michéa, "Le traitement judiciaire du critère discriminatoire de l'âge", Droit Social (2010): 1060-1069.

${ }^{35}$ Judgment of 19 January 2010, Seda Kücükdeveci v. Swedex, C-555/07, EU:C:2010:21, paragraphs 21-25.

${ }^{36}$ The idea that the principle of non-discrimination on grounds of age is an autonomous EU law principle was reaffirmed by the CJ in Pérez, Prigge, Toftgaard, Kristensen and Judgment of 8 September 2011, Hennigs v. Eisenbahn-Bundesamt and Land Berlin v. Mai, C-297/10 and C-298/10, EU:C:2011:560. The dispute between the CJ and the Advocate Generals seems to be, in this way, resolved.
} 
less favourably than another is, has been or would be treated in a comparable situation, and indirect discrimination results from an apparently neutral provision, criterion or practice which puts someone at a particular disadvantage compared with other persons, unless such provision, criterion or practice is objectively justified by a legitimate aim and the means of achieving that aim are appropriate and necessary. As results from the letter of the law and has been confirmed by the Court, only provisions, criteria or practices which constitute indirect discrimination may escape the qualification of discrimination. ${ }^{37}$

However, art. 6 no. 1 establishes a scheme of derogation specific to differences of treatment on grounds of age, which allows MS to provide that such differences do not constitute discrimination "if, within the context of national law, they are objectively and reasonably justified by a legitimate aim, including legitimate employment policy, labour market and vocational training objectives, and if the means of achieving that aim are appropriate and necessary". The Court has justified this decision of the legislator on account of the recognised specificity of age among the grounds of discrimination prohibited by the Directive. ${ }^{38}$ The idea that age is somehow different from the other factors of discrimination is also seen in recital 25 of the Directive which recognises that "differences in treatment in connection with age may be justified under certain circumstances and therefore require specific provisions which may vary in accordance with the situation in Member States" ${ }^{39}$

The specificity of the age discrimination factor allows MS to adopt measures providing for differences in treatment on grounds of age which can be classified as direct discrimination. ${ }^{40}$

In order to analyse the compatibility of national provisions with article 6 of the Directive, the CJ essentially follows three steps. First, it determines whether the national norm is encompassed by the Directive; in case of an affirmative answer, it then analyses whether such norm introduces a

\footnotetext{
${ }^{37}$ Paragraph 59 of Age Concern England.

${ }^{38}$ Age Concern England, paragraph 60. See Matthieu Houser, "La spécificité du principe de nondiscrimination en raison de l'âge", Revue Française de Droit Administratif26, no. 2 (2010): 323-333.

${ }^{39}$ For a very interesting take on the specificity of age as a factor of discrimination, see Axel Gosseries, "What makes age discrimination special: A philosophical look at the ECJ case law", Netherlands Journal of Legal Philosophy 43, no. 1 (2014): 59-80. In the article, the author examines why the "age factor" should receive a special treatment in relation to the other factors of discrimination.

${ }^{40}$ Age Concern England, paragraph 62.
} 
discrimination on grounds of age; and finally, if the norm is indeed age discriminatory, whether it is justifiable under the Directive.

Regarding the first step, i.e. in order to ascertain whether the national provision falls within the material and personal scope of the Directive, it is necessary to take into account article 3 no. 1, according to which the Directive is applicable to all persons, as regards both the public and private sectors, in relation to: conditions for access to employment; access to all types and to all levels of vocational guidance and training; employment and working conditions (including dismissals and pay); and membership of, and involvement in, an organisation of workers or employers.

However, according to recital 13, the Directive shall not apply to social security and social protection schemes whose benefits are not treated as income. According to Article 157 no. 2 TFEU, the concept of income comprises any consideration, whether in cash or in kind, which the workers receive directly or indirectly, in respect of their employment, from their employers. ${ }^{41}$ This issue was discussed in Felber ${ }^{42}$ where the CJ was asked whether the Directive precluded an Austrian norm which excluded the crediting of periods of school education completed by civil servants before the age of 18 for the purpose of the grant of pension entitlements and the calculation of their amount. According to the Court, since the retirement pension constituted a future cash payment, paid by employers to their employees, as a direct consequence of their employment relationship and its amount depended on periods of service, it had to be regarded as income within the meaning of Article 157 no. 2 TFEU. The norm fell, therefore, within the scope of the Directive.

Since article 3 no. 1 (c) explicitly refers to the public sector, there is no doubt that the Directive is applicable to the income of public servants. In Unland, the CJ confirmed that pay conditions for national judges fall within the scope of the Directive. ${ }^{43}$

Lange is a more dubious case regarding the limits of the scope of the Directive. In this ruling, the CJ was asked whether a taxation scheme, which provided that the tax treatment of vocational training costs incurred by a person differed depending on that person's age, fell within the scope of the Directive. The CJ gave a positive answer since - even though the existence

\footnotetext{
${ }^{41}$ Kristensen, paragraph 26 and Toftgaard, paragraph 26.

${ }^{42}$ Judgment of 21 January 2015, Georg Felber v. Bundesministerin für Unterricht, Kunst und Kultur, C-259/13, EU:C:2015:20.

${ }^{43}$ On the concept of pay see Kristensen, paragraphs 26-30.
} 
and scope of a right to deduct was not a precondition, as such, for access to vocational training - the resulting financial consequences could affect the actual accessibility to such training. The right to deduct had been designed to help young people pursue their studies and gain a firm position on the labour market. Therefore, the taxation scheme had to be regarded as access to vocational training within the meaning of the Directive.

In contrast, in Korkein hallinto-oikeus, ${ }^{44}$ when asked whether a national provision relating to a supplementary tax on pension income fell within the substantive scope of the Directive, the CJ gave a negative answer, since such taxation had no link with a contract of employment and derived directly and exclusively from national tax legislation applicable to all natural persons whose income from retirement pensions exceeded a certain amount. ${ }^{45}$

Regarding the second step - in order to find out whether the national provision is discriminatory on grounds of age - it is necessary to bear in mind that, according to article 2 no. 1 of the Directive, the "principle of equal treatment" implies that there shall be no direct or indirect discrimination whatsoever on any of the grounds referred to in article 1, amongst which we find age.

In certain preliminary rulings, the $\mathrm{CJ}$ decided that the national norm at issue introduced no discrimination on grounds of age. Such was the case in Tyrolean Airways, ${ }^{46}$ where the CJ considered that a provision of a collective agreement could not be regarded as indirect discrimination even though, for the purposes of grading in employment categories and determining the level of pay, it only took into account the professional experience acquired as a cabin crew member of Tyrolean Airways, while excluding identical experience acquired in the service of another airline belonging to the same group of companies. According to the Court, even though the clause would likely entail a difference in treatment according to the date of recruitment by the employer, such difference was not, directly

\footnotetext{
${ }^{44}$ Judgment of 2 June 2016, Korkein hallinto-oikeus, C-122/15, EU:C:2016:391.

${ }^{45}$ In other cases, the CJ also decided that the Directive was neither applicable to the interpretation of a national provision which forbade the accumulation of a retirement pension with pay obtained from a professional activity (Judgment of 21 May 2015, Sindicatul Cadrelor v. Ministerul Finanțelor Publice, C-262/14, EU:C:2015:336), nor to national legislation which forbade judges from combining a retirement pension with income from activities carried out in public institutions (Judgment of 13 June 2017, Eugenia Florescu et al. v. Casa Judeţeană de Pensii Sibiu et al., C-258/14, EU:C:2017:448). ${ }^{46}$ Judgment of 7 June 2012, Tyrolean Airways Tiroler Luftfahrt Gesellschaft v. Betriebsrat Bord der Tyrolean Airways Tiroler Luftfahrt Gesellschaft, C-132/11.
} 
or indirectly, based on age or on an event linked to age. ${ }^{47}$ The criterion used in the provision, i.e. experience acquired, was neither inextricably nor indirectly linked to the age of employees, even if it is conceivable that the application of such criterion would lead to some cabin crew members being promoted at a later age than the staff members who had acquired equivalent experience with Tyrolean Airways. ${ }^{48}$

Article 6 no. 2 allows MS to provide that "the fixing for occupational social security schemes of ages for admission or entitlement to retirement or invalidity benefits" does not constitute discrimination on grounds of age, provided this does not result in discrimination on grounds of sex. This provision, since it allows MS to provide for an exception to the principle of non-discrimination, must be interpreted restrictively. ${ }^{49}$ Therefore, the exception is only applicable to occupational social security schemes that cover the risks of old age and invalidity and only to the cases that are exhaustively listed therein. Following this reasoning, in Kristensen, the CJ was of the opinion that the exception foreseen in article 6 no. 2 did not cover an occupational pension scheme, under which an employer paid, as part of pay, pension contributions which increased with age. This was because, even though this age-related increases in pension contributions were part of an occupational social security scheme that covered the risk of old age, these increases did not fall within the cases referred to in article 6 no. 2 since they did not involve the "fixing [...] of ages for admission or entitlement to retirement or invalidity benefits". ${ }^{0}$

However, in Lesar, the CJ decided that national legislation, which excluded the taking into account of periods of apprenticeship and of employment, completed by civil servants before reaching the age of 18 , for the purpose of granting a pension entitlement and the calculation of such pension, constituted an expression of the freedom enjoyed by MS under article 6 no. $2 .{ }^{51}$

\footnotetext{
${ }^{47}$ Paragraph 29.

${ }^{48}$ In another case, the CJ also decided that the Directive did not preclude a national collective labour agreement by which employees, who benefited from account being taken of periods of school education for the purpose of their classification in the salary steps, to longer periods of advancement between the first and the second salary step, as long as that extension applied to every employee benefiting from the inclusion of those periods. Judgment of 21 December 2016, Daniel Bowman v. Pensionsversicherungsanstalt, C-539/15, EU:C:2016:977.

${ }^{49}$ Kristensen, paragraph 46.

${ }^{50}$ Paragraphs $40 \mathrm{ff}$.

${ }^{51}$ Paragraphs $30 \mathrm{ff}$.
} 
In Parris ${ }^{52}$ the CJ also considered to be covered by article 6 no. 2, and therefore not to constitute discrimination, an Irish norm which, in connection with an occupational benefit scheme, subjected the right of surviving civil partners of members of such scheme to receive a survivor's benefit to the condition that the civil partnership was entered into before the member reached the age of 60 , even though - in this specific case - it had been legally impossible for the member to enter into a civil partnership before that age. ${ }^{53}$

Furthermore, article 4 no. 1 of the Directive allows MS to provide that certain differences of treatment shall not constitute discrimination "where, by reason of the nature of the particular occupational activities concerned or of the context in which they are carried out, such a characteristic constitutes a genuine and determining occupational requirement" as long as "the objective is legitimate and the requirement is proportionate".

In Wolf, the CJ assessed whether a national norm which fixed the maximum age for recruitment in the fire service at 30 years might, pursuant to article 4 no. 1 of the Directive, not constitute discrimination. In this case, the CJ had the opportunity to clarify that it was not the ground on which the difference of treatment was based but a characteristic related to that ground which must constitute a genuine and determining occupational requirement. ${ }^{54}$ The possession of especially high physical capacities demanded of firefighters should be regarded as such. This characteristic is related with age and therefore fell within the meaning of article 4 no. 1. Furthermore, the CJ considered that the objective pursued by the legislation in cause - to guarantee the operational capacity and proper functioning of the professional fire service - was legitimate and the requirement was proportionate. Therefore, the Court concluded that the Directive did not preclude such norm.

Under discussion in Prigge was a clause in a collective agreement which fixed at 60 the age limit for commercial pilots to exercise their professional activity, considering that pilots no longer possess the necessary physical capabilities beyond such age. The $\mathrm{CJ}$ accepted that the aim of guaranteeing air traffic safety constituted a legitimate objective within the meaning of

\footnotetext{
${ }^{52}$ Judgment of 24 November 2016, David L. Parris v. Trinity College Dublin, C-443/15, EU:C:2016:897.

${ }^{53}$ This was a same sex couple and, at the time, the national law did not allow the constitution of such civil partnerships.

${ }^{54}$ Paragraph 35.
} 
article 4 no. 1, however it found that the measure failed the proportionality test, since national and international legislation authorised the carrying out of that activity until the age of 65 . The clause was thus considered disproportionate and precluded by the Directive.

In cases Pérez and Sorondo, the measures at issue established an age limit to apply for posts in the local police (of the municipality of Oviedo, in the first case, and of the Autonomous Community of the Basque Country, in the second). In Pérez the limit was set at 30 years and in Sorondo at 35 years. In both cases, the $\mathrm{CJ}$ accepted that the possession of particular physical capacities could be regarded as a "genuine and determining occupational requirement" for the purposes of employment as a local police officer and that the aim to safeguard the operational capacity and proper functioning of the local police service, by ensuring that newly recruited officers were able to perform the more physically demanding tasks for a relatively long period of their career, constituted a legitimate objective within the meaning of article 4 no. 1. Curiously, the CJ held that the measure at issue in Sorondo respected the principle of proportionality, whereas in Pérez the measure was seen as imposing a disproportionate requirement and therefore could not be justified under the Directive.

The Court justified the disparity of these solutions based on the fact that the duties required to be exercised by the police force in the Pérez case differed from those in Sorondo, namely, in the latter, police officers did not carry out administrative tasks but performed essentially operational duties which might imply recourse to physical force..$^{55}$

This justification seems, nonetheless, rather weak. The CJ made no reference to the need to interpret article 4 no. 1 restrictively; to the clear disparity in the various Spanish autonomous communities' legislation governing local police officers as regards the fixing of a maximum age (in some the limit is only 40, whilst others impose no limit at all); and to the fact that the condition setting a maximum age to apply to become an officer in the national police force had been abolished. In Pérez, the CJ stated that the aimed objective could be attained through less restrictive methods than that of imposing an age-limit, such as the completion of stringent physical tests. It remains to be explained why such measures could not be used in Sorondo.

${ }^{55}$ The CJ also found that in Pérez, unlike Sorondo, it was not proven that the objective of safeguarding the operational capacity and proper functioning of the police service made it necessary to maintain a particular age structure. 
In the last step, the Court analyses whether discriminatory measures can be justified because they pursue a legitimate objective. The burden of establishing the legitimacy of the aim pursued falls on the MS.${ }^{56}$ According to article 6 no. 1, MS may provide that differences of treatment on grounds of age are not discriminatory if they are justified by social policy objectives, such as those related to employment policy, labour market and vocational training. ${ }^{57}$ Following this reasoning, in the above mentioned Prigge case, the CJ stated that air traffic safety did not fall within the aims referred to article 6 no. 1 of the Directive and therefore the national measure at issue could not be justified under this norm. The objective pursued, in order to be considered legitimate under the Directive, must be of a public interest nature. The Court rejects aims which are related to purely individual reasons particular to the employer's situation, ${ }^{58}$ such as cost reduction or improving competitiveness. Objectives of budgetary equilibrium or of an administrative nature are also deemed not to fall within the wording of article 6 and have therefore been rejected. ${ }^{59}$

Very often, national legislation is silent about the objective pursued by the measure at issue. However, according to the Court, a lack of precision in the national legislation does not automatically exclude the possibility that it may be justified under article $6 .^{60}$ In such cases it is necessary to take into account other elements, derived from the global context of the measure concerned, which might indicate the underlying aim of the measure. ${ }^{61}$ Furthermore, the CJ has also stated that a change in the context of a law leading to an alteration of the aim of that law does not, by itself, preclude that law from pursuing a legitimate aim within the meaning of the Directive. ${ }^{62}$

\footnotetext{
${ }^{56}$ Age Concern England, paragraph 65.

${ }^{57}$ Age Concern England, paragraph 46, and Judgment of 18 June 2009, David Hütter v. Technische Universität Graz, C-88/08, EU:C:2009:381, paragraph 41.

${ }^{58}$ Age Concern England, paragraph 46.

${ }^{59}$ Judgment of 11 November 2014, Leopold Schmitzer v. Bundesministerin für Inneres, C-530/13, EU:C:2014:2359, paragraphs 41 and Fuchs and Köhler, paragraph 74.

${ }^{60}$ Pérez, paragraph 62.

${ }^{61}$ Fuchs and Köhler, paragraph 39. See Palacios, Petersen, Rosenbladt and Kristensen.

${ }^{62}$ Fuchs and Köhler, paragraphs 41-43. Under discussion was a law which provided for the compulsory retirement of prosecutors at the age of 65 , which had been adopted during a period of full employment and, later on, maintained during a period of unemployment. According to the CJ, a change of circumstances may lead to an alteration of the objective pursued, but that does not, by itself, preclude the law from pursuing a legitimate aim within the meaning of the Directive.
} 
Even if it pursues a legitimate aim, the national measure will only be considered justified, under the Directive, if the means to pursue such aim respect the principle of proportionality, in other words, the means used must be appropriate and they cannot exceed what is necessary to attain the objective pursued. According to the Court, national legislation will only be considered appropriate if it genuinely reflects a concern to attain it in a consistent and systematic manner. ${ }^{63}$ In order to access the necessity of a measure, account must be taken of the measure's context and the adverse effects it is likely to cause to the persons concerned. ${ }^{64}$

In most cases, the proportionality test is done by the CJ; however, there are cases where the Court leaves such exercise to the national judicature.

\section{Cases of "consequential discrimination"}

Recently, the CJ has answered various preliminary questions regarding a problem we might name as "consequential discrimination". This refers to cases where MS repealed legislation containing age-related discriminatory measures and tried to replace it by discrimination-free regimes. However, very frequently, MS encounter various problems when trying to bring about such change, namely, because they have to respect acquired rights and protect the legitimate trust of the employees who benefited from the previous system. As a consequence, the new legal regimes tend to perpetuate the discriminatory effects introduced by previous systems.

This was the case in Schmitzer, in which the Austrian legislator, as a consequence of a previous preliminary ruling, ${ }^{65}$ altered its age-based discriminatory national regime in order to create a neutral system. In order to determine the career advancement reference date, the new regime took into account periods of training and service regardless of whether these where completed by the civil servant before or after the age of 18 . However, civil servants, who suffered discrimination under the former legal situation

\footnotetext{
${ }^{63}$ In Petersen, the CJ considered that the Directive precluded a national measure, setting a maximum age for practicing as a panel dentist, in this case 68 years; the sole aim of that measure was to protect the health of patients against the decline in performance of those dentists after that age. However, the age limit did not apply to non-panel dentists. According to the Court, a measure encompassing such a broad exception cannot be regarded as essential for the protection of public health.

${ }^{64}$ Judgment of 11 April 2013, Ring v. Dansk Almennyttigt Boligselskab and Werge v. Dansk Arbejdsgiverforening, joined cases C-335/11 and C-337/11, EU:C:2013:222, paragraph 89 and Specht, paragraph 71.

${ }^{65}$ Ac. Hütter.
} 
and requested that periods prior to their eighteenth birthday be taken into account, were subjected to a three-year extension to the period required in order to progress from the first to the second incremental step in each job category and each salary group. This three-year extension was not applied to the other civil servants. The CJ decided that the new legislation not only neutralised the advantage resulting from the inclusion of periods of training and service completed before the age of 18 , but also placed at a disadvantage only the civil servants disadvantaged by the previous system. The Austrian government tried to justify the new regime through budgetary considerations and claimed that it intended to serve objectives of procedural economy, of respect for acquired rights and of protection of legitimate expectations. The Court restated that the first objectives - budgetary equilibrium and considerations of administrative nature - did not constitute legitimate aims within the meaning of the Directive, but the respect of acquired rights and the protection of legitimate expectations did indeed constitute legitimate employment-policy and labour-market objectives ${ }^{66}$ and as such they might justify, for a transitional period, the maintenance of a discriminatory system. ${ }^{67}$ They cannot, however, justify a measure that maintains, definitively, for certain persons, an age-based discriminatory treatment. ${ }^{68}$

On the other hand, in Unland, the Court accepted a new system governing the remuneration of judges, under which the pay step which they were to be allocated was determined solely on the basis of the amount received by way of basic pay under the previous age-based discriminatory remuneration system. In this case, the CJ accepted that the objective of protecting acquired rights could justify national provisions which perpetuated an age-related discriminatory treatment, as it constituted an overriding reason in the public interest. Unlike in Schmitzer, the new system was considered suited to attain the aim pursued and seemed not to go beyond what was necessary to achieve it. Given that it was a transitional derogation and potentially affected all judges, there was neither a category of "young

\footnotetext{
${ }^{66}$ Hennigs \& Mai was the first case where the Court was asked whether a discriminatory measure could be maintained in order to protect acquired rights. The Court accepted the maintenance of some discriminatory effects of the earlier system, for a limited transitional period, in order to ensure that employees did not suffer a loss of income.

${ }^{67}$ Paragraph 42.

${ }^{68}$ This position was reaffirmed in Judgment of 28 January 2015, ÖBB Personenverkehr v. Gotthard Starjakob, C-417/13, EU:C:2015:38, which is very similar to the Schmitzer case.
} 
judges" at a disadvantage nor "older judges" placed in a more favorable position.

\section{Cases of automatic termination of employment contracts due to the employee's age and the promotion of intergenerational employment as a legitimate objective}

The question of whether article 6 of the Directive precludes national provisions which foresee the automatic termination of employment contracts when the employee reaches a certain age was discussed, for the first time, in the Palacios case. This case is of utmost importance because it shows the CJ's acceptance to apply the Directive to these national regimes and to review them under the principle of non-discrimination on grounds of age, even though, according to recital 14, the Directive is not supposed to affect national provisions laying down retirement ages. According to the CJ, this recital "merely states that the directive does not affect the competence of the Member States to determine retirement age and does not in any way preclude the application of that directive to national measures governing the conditions for termination of employment contracts where the retirement age, thus established, has been reached" ${ }^{69}$ The Court thus accepted jurisdiction to rule on this matter and implicitly attributed to the national courts competence to analyse their respective regimes of mandatory retirement. ${ }^{70}$

Palacios opened the door to numerous rulings regarding this question. In these cases, MS tend to present the "need to promote intergenerational employment" as the objective of these measures. In other words, national provisions which determine the automatic termination of employment contracts of older workers are justified by the need to share employment between generations and maintain a balanced age structure in the labour market. The termination of contracts of older employees is believed to favour directly the younger workers by promoting their professional insertion.

The Court accepts the "promotion of intergenerational employment" as a legitimate objective and, in the majority of these cases, the national measures were considered to comply with the principle of proportionality, i.e. they were deemed necessary and adequate to fulfil their aim.

\footnotetext{
${ }^{69}$ Paragraph 44.

${ }^{70}$ Robin Allen, Latest CJEU Case Law on Age Discrimination, e-presentation, available at: http:// era-comm.eu/stream/allen/allen.html.
} 
Commission vs. Hungary ${ }^{71}$ is one of the few exceptions in which the national measure failed the proportionality test. At issue was the adoption of a Hungarian law requiring the compulsory retirement of judges, prosecutors and notaries when they reached the age of 62 , with the aim of setting a uniform age-limit for compulsory retirement in the public sector and establishing a more balanced age structure in the field. The Court was of the opinion that the national measure went beyond what was necessary to achieve its aim and unduly prejudiced the interests of the persons concerned, since it abruptly and significantly lowered the age-limit for compulsory retirement (from the age of 70 to 62) and forced the persons concerned to leave the labour market without having the time to take the necessary financial and economic measures.

In a nutshell, according to EU case law, article 6 no. 1 of the Directive must be interpreted as not precluding national provisions which allow for the automatic termination of employment contracts when the employee reaches a certain age, as long as such provisions are justified by a legitimate aim (and the promotion of intergenerational employment is considered as such) and the means used to attain this aim are appropriate and necessary.

Taking into consideration the response of the CJ to the vast majority of cases of this nature, we may conclude that, in practice, the principle of non-discrimination on grounds of age, as established by the Directive, offers a very low level of protection against forced withdrawal from the labour market due to the advanced age of the employee. ${ }^{72}$

\section{Some considerations on the legitimacy of the "promotion of intergenerational employment" objective}

If we consider the EU's demographic challenges, i.e. falling birth rates and an ageing population, compulsory retirement seems to be a solution that goes against the interests of society. Furthermore, bearing in mind the increase in life expectancy and the improvement in the general health of the older population, one could expect that the population would work longer. On the other hand, in EU countries with high youth unemployment rates, ${ }^{73}$ compulsory retirement - by forcing the substitution of older workers by younger ones - might seem as an apt measure to combat unemployment

\footnotetext{
${ }^{71}$ Judgment of 6 November 2012, Commission vs. Hungary, C-286/12, EU:C:2012:687.

72 Dagmar Schiek, "Age discrimination before the ECJ - conceptual and theoretical issues", Common Market Law Review 48 (2011): 790.

${ }^{73}$ See http://ec.europa.eu/eurostat/statistics-explained/index.php/Unemployment_statistics.
} 
among younger generations. ${ }^{74}$ This view is based on the so-called lump of labour theory, which literally means that if an additional older person is employed, a younger worker will be unemployed. This theory lies on the presumption that there is a fixed number of available places in the labour market and therefore it is beneficial to implement compulsory retirement systems in order to substitute the older workers by the younger ones.

Economists tend to view the lump of labour theory with great skepticism; according to them, this theory cannot be applied to a macro-economic level. ${ }^{75}$ First of all, because the labour market is not a static reality: there is no limited, fixed or predetermined number of available places; the market is a dynamic, flexible, and constantly changing reality. Furthermore, older workers will not be automatic and naturally substituted by younger ones. Due to the constant alteration of labour patterns, the labour market's entrance and exit flow are not necessarily symmetrical, i.e. an older employee's leave from the market does not automatically represent a vacancy for a younger one.

In fact, various studies demonstrate a positive correlation between employment rates of younger and older workers: an augmentation in the employment rate of older workers leads to a decrease in the unemployment rate among the younger generations.$^{76}$ Employment rates of the various

\footnotetext{
${ }^{74}$ Dewhurst, "Intergenerational", 1337.

${ }^{75}$ Simonetta Manfredi and Lucy Vickers, "Retirement and age discrimination: Managing retirement in higher education", Industrial Law Journal 58, no. 4 (2009): 343-364; Sandra Fredman, "The age of equality," in Age as an Equality Issue: Legal and Policy Perspectives, ed. Sandra Fredman and Sarah Spencer (Oxford: Hart Publishing, 2003).

${ }^{76}$ Some studies which dismiss the lump of labour theory: Adriaan Kalwij, Arie Kapteyn and Klaas de Vos, "Retirement of older workers and employment of the young", The Economist 158, no. 4 (2010): 341-359; René Böheim, "The effect of early retirement schemes on youth unemployment", IZA World of Labor 70 (2014): 1-10. https://wol.iza.org/uploads/articles/70/pdfs/effect-of-earlyretirement-schemes-on-youth-employment.pdf?v=1; Alicia Munnel and April Yanyan Wu, "Will delayed retirement by the baby boomers lead to higher unemployment among younger workers?", Working Paper no. 22 (2012), Center for Retirement Research at Boston College, https://papers. ssrn.com/sol3/papers.cfm?abstract_id=2162093; Jonathan Gruber and David Wise (eds.), Social Security Programs and Retirement around the World: The Relationship to Youth Unemployment (Chicago: University Press, 2010); Chuanchuan Zhang C., "The relationship between elderly employment and youth employment: Evidence from China", MPRA Paper no. 3722 (2012), University Library of Munich. https://mpra.ub.uni-muenchen.de/37221/. See also Ewa GałeckaBurdziak and Marek Góra, "The impact of easy and early access to old-age benefits on exits from the labour market: A macro-micro analysis", Working Paper no. 152 (2015), Center for Research on Pensions and Welfare Policies. http://www.cerp.carloalberto.org/wp-content/uploads/2015/12/ WP_152.pdf.
} 
age groups tend to move in the same direction and not in the opposite one. ${ }^{77} \mathrm{~A}$ higher percentage of older individuals active in the market will lead to more opportunities for younger workers of finding a job and an increase in their respective income. ${ }^{78}$ Some authors compare this situation with the entrance of women in the work force, which did not have a negative impact on men's employment rate. ${ }^{79}$

Nonetheless, the lump of labour theory might make sense when applied to organizations or institutions which have a fixed or predetermined number of workplaces available, especially if older and younger employees share identical skills and competences, making it easier to operate substitutions among them. Universities, for instance, are such an example: if there are a fixed number of available posts, an increase of older academics will necessarily lead to a decrease in the presence of younger ones. ${ }^{80}$

In these specific cases, where there is a fixed number of places, the introduction of compulsory retirement policies might indeed have beneficial effects.

However, it seems to us that the CJ tends to accept rather too swiftly the "promotion of intergenerational employment" as a legitimate objective when presented by MS in order to justify compulsory retirement schemes, especially when the appropriateness of the measures used to attain such objective is not validated by economic data.

Furthermore, the CJ tends to consider the measures as being necessary and adequate, without taking into consideration the context in which they are implemented, i.e. regardless of whether they will be applied to a closed organization or to a broader reality, such as sector of the economy or the entire national market. For instance, in Georgiev the measure was applied to university professors, in Fuchs and Köhler to public servants and in Hörnfeldt to the whole Swedish market. However, as mentioned

\footnotetext{
${ }^{77}$ For example, in the 70s, in Germany, a measure promoting the retirement of older workers is associated with an increase of unemployment rates among younger generations. Recent studies carried out in the US confirm this theory. Dewhurst, "Intergenerational", $1351 \mathrm{ff}$.

${ }^{78}$ Ray Barrell, Simon Kirby and Ali Orazgani, "The macroeconomic impact from extending working lives", Working Paper no. 95 (2011), Department for Work and Pensions. https://www. gov.uk/government/uploads/system/uploads/attachment_data/file/214392/WP95.pdf. Ros Altmann, "A new vision for older workers: Retain, retrain, recruit", Report to Government (2015), Department for Work and Pensions. https://www.gov.uk/government/uploads/system/uploads/ attachment_data/file/411420/a-new-vision-for-older-workers.pdf.

${ }^{79}$ Gruber and Wise, "Social Security".

${ }^{80}$ See Georgiev.
} 
above, the adequacy of the measure will depend on the context in which it is applied. Forcing older employees to exit open and dynamic markets might be counterproductive and lead to higher unemployment among younger generations. ${ }^{81}$

For instance, in Rosenbladt, the CJ accepted the justification presented by the German government regarding a national provision which considered valid clauses on automatic termination of employment contracts on the grounds that the employee had reached a certain age, based on the argument that the lawfulness of such clauses is accepted in a number of other MS and reflects a political and social consensus which has endured for many years. ${ }^{82}$

The easiness with which the ECJ accepts these justifications was underlined by one of the parties of the proceedings that lead to the Georgiev ruling. In this case, the provision under analysis determined that, after the age of 65 , university professors could only continue to work by means of fixed-term one-year contracts, renewable at most twice, and established their compulsory retirement once they reached the age of 68 . Mr. Georgiev, in his written observations, alerted the Court to the fact that the national legislation was not aligned to the reality of the labour market concerned. According to his submission, the average age of university professors was elevated due to an absence of interest on the part of young people in a career as a professor. In his view, the legislation at issue was thus inept to encourage the recruitment of young people. If these allegations correspond to reality, they serve to illustrate the potential inadequacy of compulsory retirement measures to pursue the promotion of intergenerational employment even in closed institutions with a fixed number of posts.

There are various other arguments militating against the introduction of a mandatory retirement age. Studies demonstrate that augmenting the average duration of working life leads to economic growth, a considerable increase in gross domestic product, a reduction of fiscal spending, and contributes to the neutralization of the EU's demographic problem. ${ }^{83}$ From the employer's perspective, research demonstrates that older workers are just

\footnotetext{
${ }^{81}$ Even though, in Hörnfeldt, the CJ seems to recognise the need to consider the context in which the measure will be applied. See paragraph 34 .

${ }^{82}$ Paragraph 43.

${ }^{83}$ Altmann, "Report".
} 
as productive as younger ones: ${ }^{84}$ factors such as experience, strategy and skills tend to compensate for the functional decline related with age ${ }^{85}$ For business, maintaining older workers employed contributes to the retention of experience and know-how and the reduction of recruitment and training costs. Lastly, from the perspective of the worker, studies demonstrate that the maintenance of a professional activity contributes to physical and mental health. ${ }^{86}$

\section{Some final remarks}

After a very generous approach to the principle of non-discrimination on grounds of age, reflected in the Mangold case, the CJ adopted, in subsequent cases, a considerably more refrained attitude. ${ }^{87}$ Nonetheless, the case law of the CJ on this matter is still under development and, as such, the Court has not yet been able to adopt an entirely consistent approach. ${ }^{88}$

According to some scholars, ${ }^{89}$ the CJ's case law regarding this subject has raised more questions than it has brought answers, namely on how to find an equilibrium between the prohibition of age discriminating and the respect for the traditional use of age as a factor of differentiation in social and labour policies.

Certain CJ decisions seem to be contradictory. For instance, the Spanish cases Sorondo and Pérez or the Danish cases Andersen, Landin e Toftgaard.

\footnotetext{
${ }^{84}$ Liz Yeomans, "An update of the literature on age and employment", Research Report RR832 (2011), Health and Safety Laboratory. http://www.hse.gov.uk/research/rrpdf/rr832.pdf.

${ }^{85}$ Michael Silverstein, "Meeting the challenges of an aging workforce", American Journal of Industrial Medicine 51 (2008): 269-280. Victoria Büsch, Svenn-Åge Dahl and Dennies Dittrich, "An empirical study of age discrimination in Norway and Germany", Applied Economics 41 (2009): 633-651.

${ }^{86}$ On how retirement may contribute to social isolation, inactivity and depression, see Felix Neto, "As pessoas idosas são pessoas: Aspectos psico-sociais do envelhecimento", Revista de Psicologia, Educação e Cultura 3, no. 2 (1999): 297-322. Also, Manfredi and Vickers, "Retirement". According to data collected by the Eurofund, about $56 \%$ of retirees would rather have maintained their professional activity, and the majority of workers over 65 claim they are particularly satisfied with their work, Work Preferences after 50 (Luxemburg: Publications Office of the European Union, 2014). https://www.eurofound.europa.eu/publications/foundation-findings/2014/quality-of-life/ foundation-findings-work-preferences-after-50.

${ }^{87}$ See Linda Senden, "Case C-227/04 P, Maria-Luise Lindorfer v. Council of the European Union, Judgment of the Court (Grand Chamber) of 11 September 2007", Common Market Law Review 47 (2010): 521-535.

${ }^{88}$ See Numhauser-Henning, "The EU ban", 413. The author points out that the Court's intensive use of the principle of proportionality results in very unpredictable solutions.

${ }^{89}$ Schiek, "Age discrimination", 786.
} 
Even if the ECJ tried to justify the disparity in these solutions, we are not fully convinced. These cases illustrate how the question of compatibility with the Directive on national age-discriminatory measures is dependent on questions of detail and not of general principles, and how, when dealing with extremely similar situations, the $\mathrm{CJ}$ reached different conclusions. If in cases such as Andersen and Toftgaard, the CJ considered that workers who have reached a certain age might wish to remain employed instead of retiring, in Landin, the Court abandoned such considerations and reduced the problem to knowing whether the workers, by exiting the labour market earlier, would suffer a significant reduction in their retirement pension in the long term.

In our opinion, the CJ's application of the proportionality test lacks consistency. For instance, as we have mentioned above, in Toftgaard and Pérez, the CJ decided that the measures at issue failed the proportionality test since their respective objectives were achievable through less restrictive or more appropriate measures. However, in Landin and Sorondo, even though the scenarios were quite similar, the $\mathrm{CJ}$ found that the Directive did not preclude the national provisions and made no mention to the possibility of pursuing their respective aims through less restrictive measures.

Another example of a rather lenient application of the principle of proportionality by the $\mathrm{CJ}$ is the above-mentioned Abercrombie \& Fitch Italia case, in which the Court accepted a provision allowing the conclusion of on-call contracts as long as the workers were under 25 , in order to combat youth unemployment. As remarked by certain commentators, the weakness of the arguments presented by the Italian Government and accepted by the CJ - which consist of general remarks on how the measure will facilitate the entry of young workers in the market without being corroborated by any concrete data - is quite striking.

This inconsistency is rather worrisome since it generates uncertainty, at the MS's level, regarding the validity of national norms which establish differential treatments based on age. ${ }^{90}$

The vast majority of these cases are preliminary rulings in which the CJ's competence is limited to the interpretation of EU law, leaving to national courts the application of the CJ's interpretation to the concrete case. However, the $\mathrm{CJ}$ has been criticised for the lack of more detailed

${ }^{90}$ Schiek, "Age discrimination", 789. 
orientations, in particular regarding the application of the principle of proportionality.

Among the various age discrimination cases, we find that the CJ applied different levels of scrutiny. In some cases, the control was rather bland. We are dealing with fundamental rights and, therefore, the standard should be quite strict.

The age factor receives a more generous treatment than the other factors of discrimination due to the traditional and historical use of age, by the various MS, as a structural element of their labour and social policies. However, today, the EU is an essentially tertiary economy, and adult workers face flexible labour contracts intercalated with periods dedicated to training or unemployment phases. At the same time, civil society is increasingly inept at dealing with an aging population. Bearing this social and economic scenario in mind, it seems urgent to adopt more flexible paradigms and, as far as possible, to promote active aging. ${ }^{91}$

\section{Bibliography}

Allen, Robin. Latest CJEU Case Law on Age Discrimination, e-presentation.

Altmann, Ros. "A new vision for older workers: Retain, retrain, recruit". Report to Government (2015), Department for Work and Pensions.

Barrell, Ray, Simon Kirby and Ali Orazgani. “The macroeconomic impact from extending working lives”. Working Paper no. 95 (2011), Department for Work and Pensions. Böheim, René. “The effect of early retirement schemes on youth unemployment”. IZA World of Labour 70 (2014): 1-10.

Büsch, Victoria, Svenn-Åge Dahl and Dennies Dittrich. "An empirical study of age discrimination in Norway and Germany”. Applied Economics 41 (2009): 633-651.

Cavallini, Joël. "De la suppression des restrictions à la conclusion d'un contrat à durée déterminée lorsque le salarié est un senior”. La Semaine Juridique Social 1414 (2005): 25-28.

Dewhurst, Elaine. "Intergenerational balance, mandatory retirement and age discrimination in Europe: How can the ECJ better support national courts in finding a balance between the generations?”. Common Market Law Review 50, no. 5 (2013): 1333-1362.

Dubos, Olivier. "La Cour de justice, le renvoi préjudiciel, l'invocabilité des directives: De l'apostasie à l'hérésie?". La Semaine Juridique Edition Générale 26 (2006): 1295-1297.

\footnotetext{
${ }^{91}$ In this sense, Schiek, "Age discrimination", 783 and Ann Numhauser-Henning, “The EU ban on age-discrimination and older workers: Potentials and pitfalls", International Journal of Comparative Labour Law 29, no. 4 (2013): 402.
} 
Fontanelli, Filippo. "General principles of the EU and a glimpse of solidarity in the aftermath of Mangold and Kücükdeveci”. European Public Law 17 (2011): 225-240.

Fredman, Sandra. "The age of equality". In Age as an Equality Issue: Legal and Policy Perspectives, edited by Sandra Fredman e Sarah Spencer. Oxford: Hart Publishing, 2003.

Gałecka-Burdziak, Ewa and Marek Góra. "The impact of easy and early access to old-age benefits on exits from the labour market: A macro-micro analysis". Working Paper no. 152 (2015), Center for Research on Pensions and Welfare Policies.

Gosseries, Axel. "What makes age discrimination special: A philosophical look at the ECJ case law". Netherlands Journal of Legal Philosophy 43, no. 1 (2014): 59-80.

Gruber, Jonathan and David Wise (eds.). Social Security Programs and Retirement around the World: The Relationship to Youth Unemployment. Chicago: University Press, 2010.

Houser, Matthieu. "La spécificité du principe de non-discrimination en raison de l'âge". Revue Française de Droit Administratif 26, no. 2 (2010): 323-333.

Jans, Jans H. "The effect in national legal systems of the prohibition of discrimination on grounds of age as a general principle of community law". Legal Issues of Economic Integration 34 (2007): 53-66.

Kalwij, Adriaan, Arie Kapteyn and Klaas de Vos. "Retirement of older workers and employment of the young". The Economist 158, no. 4 (2010): 341-359.

Kapp, Marshall. "Looking at age discrimination laws through a global lens". Generations - Journal of the American Society on Aging 37, no. 1 (2013): 70-75.

Leclerc, Olivier. "Le contrat de travail des seniors à l'épreuve du droit communautaire". Recueil Dalloz 8 (2006): 558-561.

Manfredi, Simonetta and Lucy Vickers. "Retirement and age discrimination: managing retirement in higher education". Industrial Law Journal 58, no. 4 (2009): 343-364.

Meyer-Heine, Anne. "La prise en compte des seniors par un traité sexagénaire: Pour une nouvelle orientation des politiques publiques". Revue de l'Únion Européene 619 (2018): 370-380.

Michéa, Frédérique. "Le traitement judiciaire du critère discriminatoire de l'âge". Droit Social (2010): 1060-1069.

Muir, Elise. "Of ages in - and edges of - EU law". Common Market Law Review 48 (2011): 39-62.

Munnel, Alicia and April Yanyan Wu. "Will delayed retirement by the baby boomers lead to higher unemployment among younger workers?”. Working Paper no. 22 (2012), Center for Retirement Research at Boston College.

Neto, Felix. "As pessoas idosas são pessoas: Aspectos psico-sociais do envelhecimento". Revista de Psicologia, Educação e Cultura 3, no. 2 (1999): 297-322. 
Numhauser-Henning, Ann. "The EU ban on age-discrimination and older workers: Potentials and pitfalls". International Journal of Comparative Labour Law 29, no. 4 (2013): 391-414.

Papadopulos, Thomas. "Criticizing the horizontal direct effect of the EU general principle of equality”. European Human Rights Law Review 4 (2011): 437-447.

Petitdemange, Anne-Sophie. "Une application anticipée des directives non transposées?", Gazette du Palais 102-103, no. 1 (2006): 22-23.

Reich, Norbert. General Principles of EU Civil Law. Cambridge: Intersentia Publishing, 2014.

Schiek, Dagmar. "Age discrimination before the ECJ - conceptual and theoretical issues". Common Market Law Review 48 (2011): 777-799.

Senden, Linda. "Case C-227/04 P, Maria-Luise Lindorfer v. Council of the European Union, Judgement of the Court (Grand Chamber) of 11 September 2007". Common Market Law Review 47 (2010): 521-535.

Silverstein, Michael. "Meeting the challenges of an aging workforce". American Journal of Industrial Medicine 51 (2008): 269-280.

Vincent, Xavier. "La cessation des fonctions de pilote du transport aérien public en raison de l'âge et la mise à la retraite". Droit Social 6 (2007): 761-768.

Yeomans, Liz. "An update of the literature on age and employment", Research Report RR832 (2011), Health and Safety Laboratory.

Zhang C., Chuanchuan. "The relationship between elderly employment and youth employment: evidence from China”. MPRA Paper no. 3722 (2012), University Library of Munich. 